\title{
原著
}

\section{脳動脈瘤処 置後の再出血}

\author{
高橋 明弘，大田 英 則 \\ 鈴木 明文, 安井 信之
}

\section{Rebleeding After Clipping of Aneurysm}

Akihiro Takahashi, M.D., Hidenori Ohta, M.D., Akifumi Suzuki, M.D., and Nobuyuki Yasul, M.D.

Department of Surgical Neurology, Research Institute for Brain and Blood Vessels-AKITA, Akita, Japan

Summary : Neck clipping was performed on 835 aneurysms (698 cases) in our institute from April 1976 till December 1985, and postoperative recurrent hemorrhage occured in seven cases $(0.8 \%)$.

It was presumed that postoperative recurrent hemorrhage was due to the "incomplete clip in four cases and due to the "slipped clip" in three cases. Three aneurysms that were treated by neck clipping combined wiht coating because of the inability to obliterate the neck completely, rebled 24-57 days after the operation. It is doubtful, in those cases, whether the best coating material was selected and whether the aneurysmal portion was covered entirely.

One case was a so called "miss clip"

In three cases, slippage of the tip of the blade was observed at the reoperation. The "slipped clip" was caused by a) selection of an inappropriate clip for a given aneurysm or b) inaccurate clip placement.

As postoperative blood pressure was high in six cases, hypertension might have partially caused the rupture of the residual neck or the slip off of the aneurysm clip.

Key words :

- cerebral aneurysm

- incomplete clip

- slipped clip

- failed aneurysm

surgery

- rebleeding

\section{はじめに}

頭蓋内囊状動脈瘤根治術として, 動脈瘤 neck の clipping あるいは ligation が行われ, 現在, 最も理想的な処置法と されている. broad neck などにより完全な clipping また は ligation が困難な場合は, coating あるい wrapping により動脈瘤を補強するのが一般的である，ところが，脳 動脈瘤に対し確実な処置を行ったと思われても, 数多い症 例の中には，処置が不完全で再出血をきたす症例がある. 当科にても脳動脈瘤 clipping 後の再出血を 7 症例経験
しており, それら症例の治療上の問題を検討し, 若干の考 察を加え報告する。

\section{対}

1976年 4 月より 1985年12月までに当科において開頭根治 術を行った脳動脈瘤698症例, 835個中, 再出血をきたした 7 症例 $(0.8 \%)$ を対象とした (Table 1). 内訳は, 前交通動 脈瘤 5 例, 内頸動脈瘤 1 例, 中大脳動脈瘤 1 例である. な お, 全例が破裂脳動脈瘤処置後であり, 非破裂脳動脈瘤処 置後に出血した例は経験していない. 


\section{症例}

〈症例 1 〉63歳，男性.

1977年10月12日，クモ膜下出血発作があり，左頸動脈撮 影にて，前交通動脈瘤を発見（Fig. 1 a)。10月20日，両側 前頭開頭術施行．前交通動脈自体が動脈瘤化しており，動 脈瘤の dome を一部切除して, Weck's clip にてクリップ し，Biobondにて coating した。術後12日目の左頸動脈撮
影で，動脈瘤は縮小しているが大部分は残存していた (Fig. 1 b)。術後57日目に再出血発作を起こし死亡した。

〈症例 2〉67歳, 女性

1978年 8 月 15 日，クモ膜下出血発作があり，左頸動脈撮 影にて前交通動脈瘤を発見 $($ Fig. 2 a)，8 月24日，両側前 頭開頭術施行。術中動脈瘤 neck が裂け，裂けた neck を 凝固し，Weck's clipにてクリップした。前交通動脈から

Table 1 List of cases who underwent rebleeding after neck clipping of aneurysm

\begin{tabular}{|c|c|c|c|c|c|c|c|c|}
\hline \multirow{2}{*}{$\begin{array}{c}\text { Case } \\
\text { Age Sex }\end{array}$} & \multirow{2}{*}{$\begin{array}{c}\text { Site of } \\
\text { aneurysm }\end{array}$} & \multicolumn{2}{|c|}{ Preoperative Grade } & \multirow{2}{*}{ Treatment } & \multirow{2}{*}{$\begin{array}{l}\text { Blood } \\
\text { pressure }\end{array}$} & \multirow{2}{*}{$\begin{array}{l}\text { Interval of } \\
\text { rebleeding }\end{array}$} & \multirow{2}{*}{$\begin{array}{l}\text { Cause of } \\
\text { rebleeding }\end{array}$} & \multirow{2}{*}{ Clinical result } \\
\hline & & Hunt \& Kosnik & ANK & & & & & \\
\hline $\begin{array}{c}77-1825 \\
63 \mathrm{M}\end{array}$ & Aco (big) & 3 & 3 & $\begin{array}{c}\mathrm{NC}+\text { Coating } \\
\text { Biobond }\end{array}$ & $140 \sim 200$ & 57 days & incomplete clip & dead \\
\hline $\begin{array}{c}78-1668 \\
67 \mathrm{~F}\end{array}$ & Aco & 3 & 2 vs & $\begin{array}{c}\text { NC }+ \text { Coating } \\
\text { Muscle } \\
\text { Biobond }\end{array}$ & $140 \sim 160$ & 41 days & incomplete clip & full dependent \\
\hline $\begin{array}{c}85-1951 \\
50 \mathrm{M}\end{array}$ & Aco & 4 & $4 \mathrm{ich}$ & $\begin{array}{c}\mathrm{NC}+\text { Coating } \\
\text { Bemsheet } \\
\text { Biobond }\end{array}$ & $140 \sim 160$ & 24 days & incomplete clip & partially dependent \\
\hline $\begin{array}{c}81-1384 \\
58 \mathrm{~F}\end{array}$ & Rt IC-PC & 3 & 3 vs & $\mathrm{NC}$ & $120 \sim 140$ & 1 day & incomplete clip & full dependent \\
\hline $\begin{array}{c}82-0493 \\
31 \mathrm{M}\end{array}$ & Aco & 2 & 2 & $\begin{array}{c}\text { NC+Coating } \\
\text { Muscle } \\
\text { Aron alpha } \\
\text { Biobond }\end{array}$ & 200 & 11 days & slipped clip & dead \\
\hline $\begin{array}{c}84-0218 \\
54 \mathrm{M}\end{array}$ & Aco & 4 & $\begin{array}{c}5 \mathrm{~b} \text { sah } \\
\text { ich }\end{array}$ & $\mathrm{NC}$ & 200 & 17 days & slipped clip & partially dependent \\
\hline $\begin{array}{c}85-2990 \mathrm{Lt} \\
53 \mathrm{M}\end{array}$ & MCA (giant) & 4 & $5 b$ ich & $\mathrm{NC}$ & $140 \sim 160$ & 4 days & slipped clip & partially dependent \\
\hline
\end{tabular}

$\mathrm{ANK}^{1)}$ : clinical grading for cerebral aneurysms (Akita Nohken, 1982).

Aco indicates anterior communicating artery, IC-PC : internal carotid artery-posterior communicating artery, MC : middle cerebral artery, NC : neck clipping.

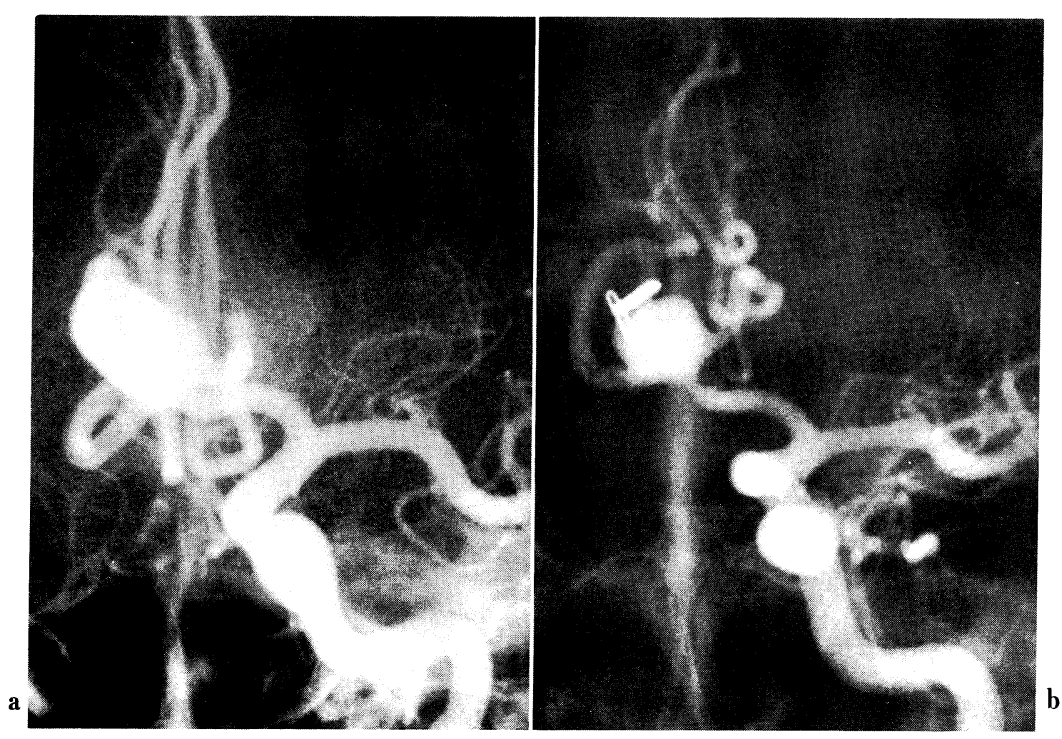

Fig. 1 Case 1. Left carotid angiograms. a: Preoperative angiogram showing an Aco aneurysm. b: Postoperative angiogram (12 days after the operation) showing the Aco aneurysm that is only slightly smaller. 


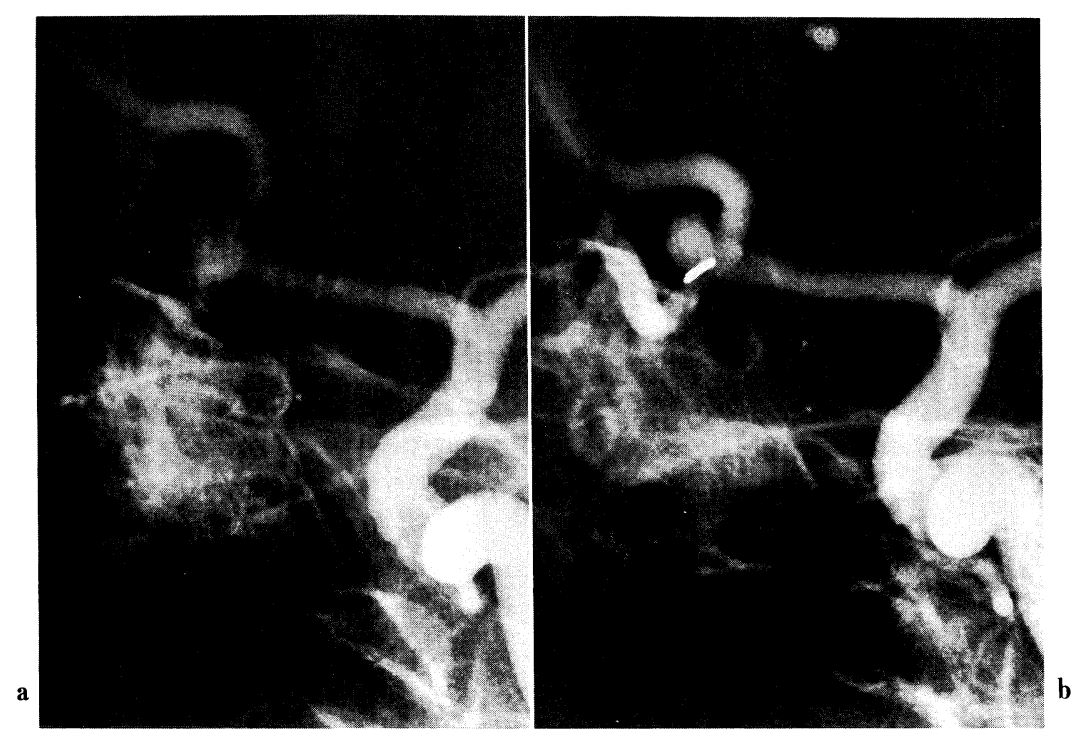

Fig. 2 Case 2. Left carotid angiograms. a: Preoperative angiogram showing an Aco aneurysm. b: Postoperative angiogram (two months after the operation) showing a small aneurysmal clip at the region of the anterior communicating artery and a new aneurysm at the tip of the clip.

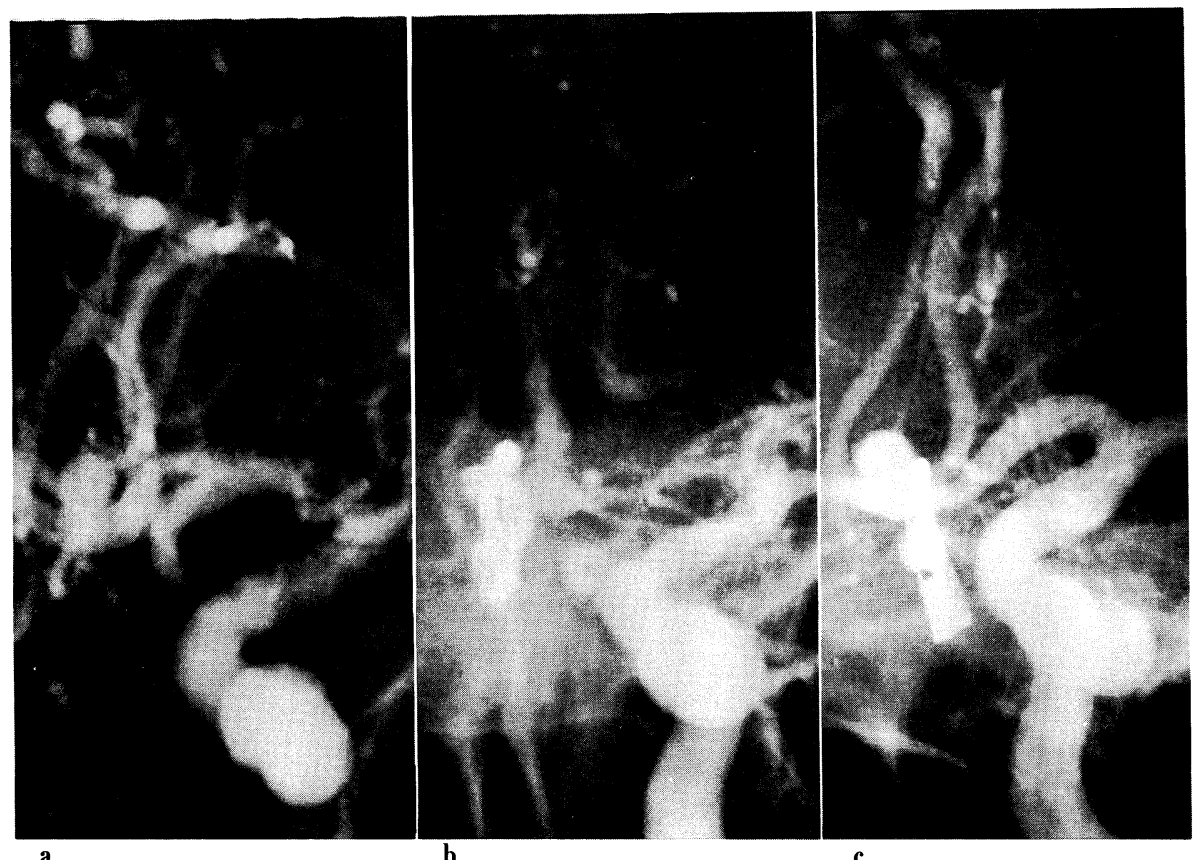

Fig. 3 Case 3. Left carotid angiograms. a: Preoperative angiogram showing an Aco aneurysm. b: Postoperative angiogram (eight days after the first operation) showing the sac obliterated. c: Angiogram after the second subarachnoid hemorrhage (SAH) attack (29 days after the first operation) showing a recurrent Aco aneurysm.

右 $\mathrm{A}_{2}$ にかけて動脈瘤の neck を形成しており，筋肉片， Biobondにて coating した. 10月 6 日，再出血発作. 10月 25日の左頸動脈撮影にて, clip の横に動脈瘤を認めた(Fig. 2 b). 一般状態不良のため再手術は行わなかった。

\section{〈症例 3〉 50歳，男性.}

1985年 8 月 6 日，クモ膜下出血発作があり，左頸動脈撮 影にて前交通動脈瘤を発見 (Fig. 3 a). 8 月 7 日, 雨側前 頭開頭術施行. premature rupture をきたし, dome coagulationにて動脈瘤を縮小させ neck clipping を行った。前 交通動脈自体が動脈瘤化しており，Bemsheet, Biobond に 


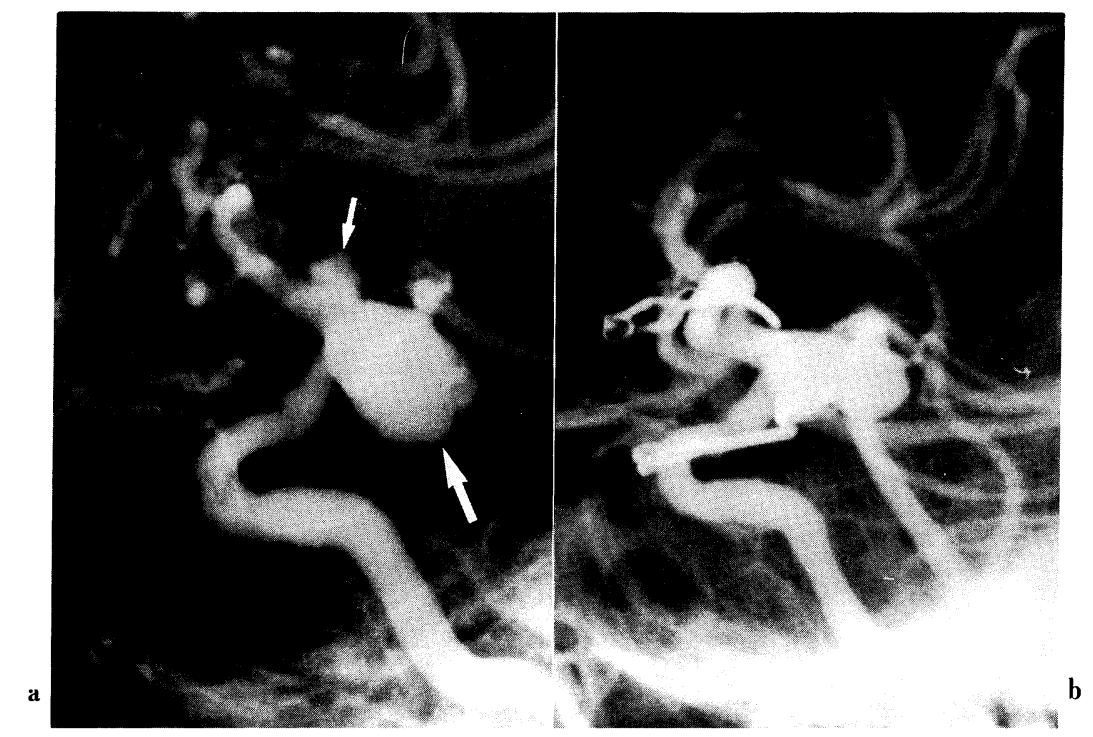

Fig. 4 Case 4. Right carotid angiograms. a: Preoperative angiogram showing IC-anterior choroidal artery aneurysm (small arrow) and IC-PC aneurysm (large arrow). b: Postoperative angiogram (two months after the first operation) showing the sac of the IC-anterior communicating artery aneurysm obliterated but the IC-PC aneurysm enlarged.

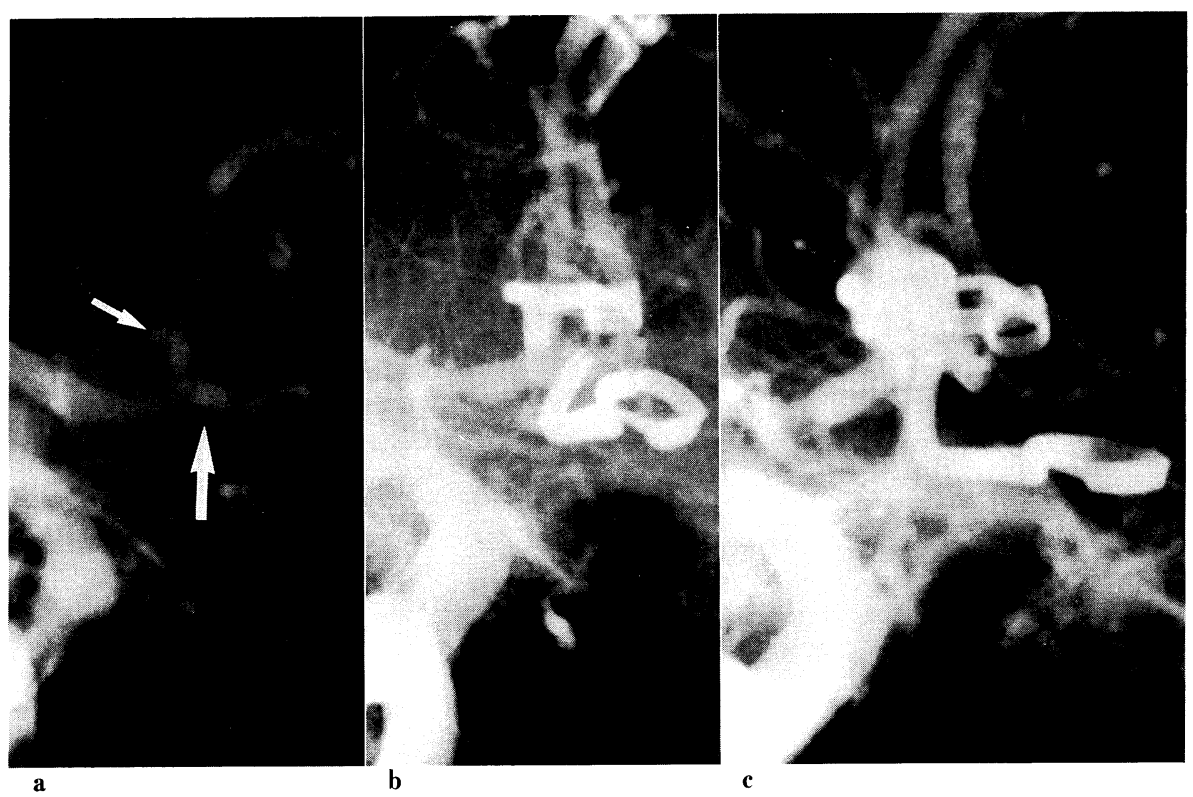

Fig. 5 Case 5. Right carotid angiograms. a: Preoperative angiogram showing a right $\mathrm{A}_{1}-\mathrm{A}_{2}$ aneurysm (large arrow) and a right $\mathrm{A}_{2}$ aneurysm (small arrow). b: Postoperative angiogram (six days after the first operation) showing both sacs obliterated. c: Angiogram after the second SAH attack (12 days after the first operation) showing the right $\mathrm{A}_{2}$ aneurysm and the slip off of the aneurysms clip.

て coating も行った. 8 月14日, 左頸動脈撮影にて動脈瘤 の消失を確認した (Fig. 3 b).ところが，9月1日， spinal drainage が血性となる。9 月 4 日, 左頸動脈撮影にて動 脈瘤の新生を確認 (Fig. 3 c)。9 月13日, 再手術にて前交 通動脈を trapping した。
〈症例 4〉58歳, 女性.

1981年 8 月 8 日, クモ膜下出血発作があり, 右頸動脈撮 影にて右内頸-後交通動脈分岐部之前脈絡動脈分岐部に 2 個の動脈瘤 (Fig. 4 a). 左頸動脈撮影にて左内頸-後交通動 脈分岐部に 1 個の動脈瘤を発見. 破裂は右内頸動脈瘤と判 断し，9月 3 日，右前頭側頭開頭術施行. 2 個の動脈瘤の 


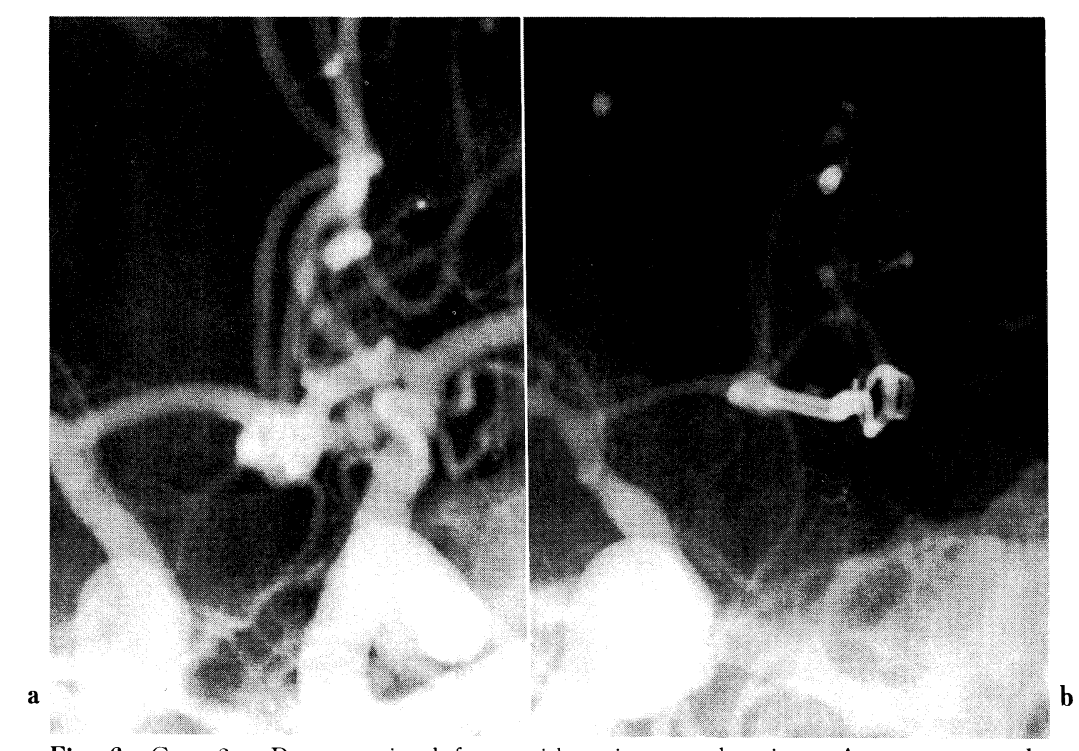

Fig. 6 Case 6. a: Preoperative left carotid angiogram showing a Aco aneurysm. b: Postoperative right carotid angiogram (7 days after the first operation) showing the sac obliterated.

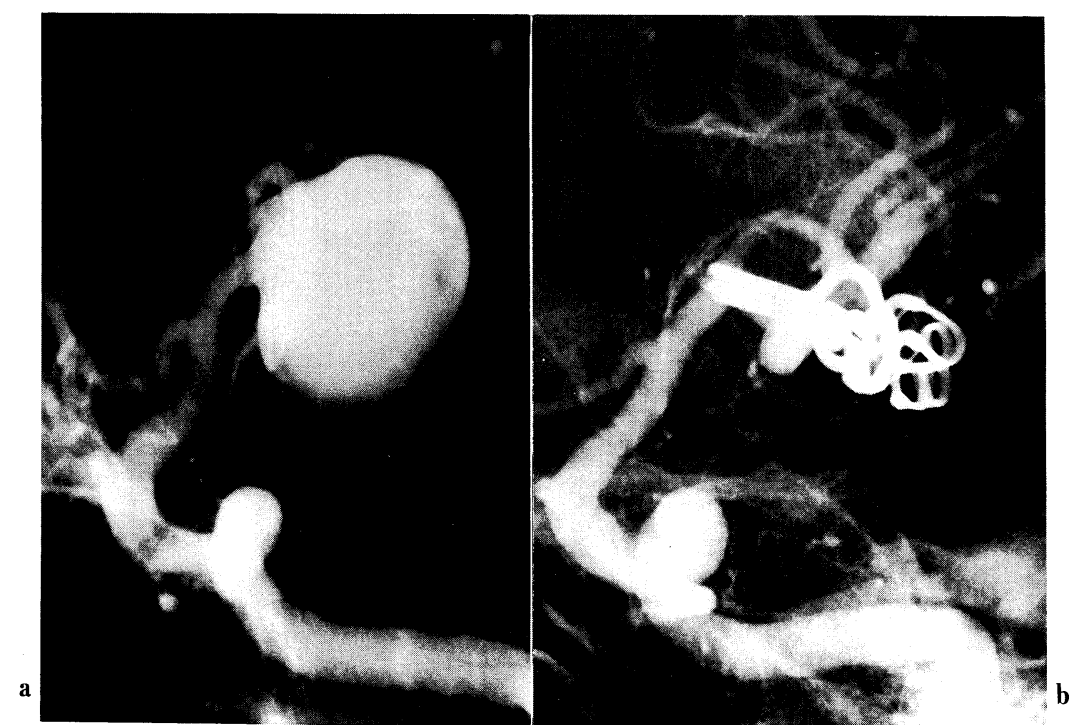

Fig. 7 Case 7. Left carotid angiogram (oblique view). a: Preoperative angiogram showing a left MC giant aneurysm. b: Postoperative angiogram showing the sac obliterated by long clips.

neck clipping を行った. 9 月 4 日，および 9 月25日，再 出血発作をきたす。今回は左内頸動脈瘤の破裂と考え, 左 内頸動脈瘤の neck clipping を行ったが破裂した所見はな かった. 10月13日，右頸動脈撮影にて， clipの横に右内頸 一後交通動脈瘤の再増大を認めた (Fig. 4 b). 今回, ビデオ を詳細に検討したところ初回手術時に neck が一部残存し ていた。

〈症例 5〉31歳, 男性.

1982年 3 月 22 日, クモ膜下出血発作があり, 右頸動脈撮
影にて前交通動脈瘤を発見 (Fig. 5 a). 3 月25日，両側前 頭開頭術施行. 右 $\mathrm{A}_{1} \mathrm{~A}_{2}$ 接合部の前向きの小動脈瘤と, 右 $\mathrm{A}_{2}$ 後方に neck を有し後乃向きの細長い動脈瘤を認め た. premature ruptureがあり，2 個の動脈瘤の neck 近く を凝固している．前向きの動脈瘤は J 型の clip でクリッ プし，後ろ向きの動脈瘤は空つきの直角 clipにてクリッ プした。筋肉片，Aron alpha, Biobondによる coating も 併用した。3 月31日, 右頸動脈撮影にて動脈瘤の消失を確 認した (Fig. 5 b)。 4 月 6 日, 再出血発作. 右頸動脈撮影 にて前交通動脈瘤の再発を認め，同日，再手術を行った。 
後ろ向きの動脈瘤に使用した空つき直角 clip が slip out し ていた(Fig. 5 c).

〈症例 6〉54歳, 男性.

1984年 1 月30日，クモ膜下出血発作があり，左頸動脈撮 影にて前交通動脈瘤を発見（Fig. 6 a)。同日，両側前頭開 頭術施行. L 型 clip を用い左 $\mathrm{A}_{2}$ を一部はさむようにクリ ップした。 2 月 6 日, 頸動脈撮影にて動脈瘤の消失を確認 した (Fig. 6 b)。 2 月12日, 再手術にて clip の slip out を確 認，前交通動脈を trapping した.

〈症例 7〉 53歳, 男性.

1985年12月 5 日, クモ膜下出血発作があり, 左頸動脈撮 影にて左中大脳動脈に giant aneurysm を認め(Fig. 7 a), 同日，左前頭側頭頭頂開頭術施行. Sugita No. 90, No. 19 の 2 本の long clip を平行にかけた. 12月 9 日, 再出血発 作. 再手術にて clipの slip out を確認, クリップをかけ直 した。

\section{考察}

手術用顕微鏡の導入, 種々の形状の動脈瘤用 clip の開 発，術前術後管理がめざましく発展したことなどにより， 脳動脈瘤破裂によるクモ膜下出血の治療上残された問題は, 脳血管攣縮のみの感さえある。ところが，まれではあるが, 手術により根治したと思った動脈瘤から再出血することが ある。

脳動脈瘤根治の原則は clip を母血管と平行にかけ, neck を残さず，母血管に狭窄を作らないことである2). broad neck な゙の理由により完全な neck clipping が行え ない場合には，不完全な方法ではあるが, coating, wrapping の併用が必要となる. wrappingの材質について蛯名 $ら^{3)}$ は, Bemsheet が血管壁との密着性に富み, cotton fiber の網目状構造間隙に collagen fiber が増生し強力な補 強を完成するため, 最も優れた材質であるとしている，完 全な neck clipping ができなかった〈症例 1，2，3〉に coating を併用しているが筋肉片, Biobond を使用し材質 が最適でなかったのと dome, neck, 母血管を含めて間隙な しに包み込んでいなかった点が反省点としてあげられる.

手術にて完全な neck clipping を行った, あるいは行っ たと思っても不十分な場合があり，その原因として Fox ${ }^{4)}$ は (a) a faulty clip mechanism, (b) selection of an inappropriate clip for a given aneurysm, (c) inacurrate clip placement, (d) failure to use additional clip on one aneurysm; and / or, (e) clip fatigue from a combination of pulsatile or static stress and metallic corrosion と分類して いる.（a）〜 (d) は手術法に原因を求めており，(e)は clip
の性状に原因を求めている.

〈症例 4〉は, 手術時 neck が残存していることに気づ かず，今回のビデオの詳細な検討により neck の残存が判 明した。いわば Fox の (c)と言えるものである.〈症例 5 , 6,7〉は, clip の選択または neck clipping の仕方が不適 当と考えられた。〈症例 5 〉は, blade 全体で辛じて neck clippingを行い coatingによる補強を加えた. 再手術にて clip 先端が slip out していたが, microscopic な neckの残 存，または凝固あるいは permanent clip による動脈壁の損 傷5)があった可能性もある. spring clipにて広基厚壁動脈 瘤の neck clippingを行った場合, spring clipにはblade 近位部で締挟力が強く, blade 先端へいくほど締挟力が弱 いという特性がある ${ }^{6)}$ えに，近位部で厚い部分を clip し たため, 遠位部での締挟力がさらに弱くなり, blade 近位 部を軸として遠位部が slip out する可能性がある。〈症例 6〉では, L 型 blade の近位部で壁の厚い $\mathrm{A}_{2}$ を挟んだこ とで動脈瘤を挟んでいる blade の遠位部の締挟力が不十分 となった可能性がある.〈症例 7〉では，2本の long clip を平行にかけたが， 2 本とも blade 遠位部の締挟力が不十 分であった可能性がある. Rosenbaum ${ }^{7)}$ は, 強力な clip のために壊死を起こし clipping 部より再出血をきたした 例の経験も報告もないことから, 広基厚壁の動脈瘤には締 挟力の強い clip を用いるべきであると強調している.さ らに周囲脳組織の clip head のの加重が clip の slip out を 助長する可能性があり, clip head への配慮が必要である. 今回対象例には, clip 自体の性状に原因を求めなければ ならない症例は含まれていなかった。

Yaşargil は, bipolar coagulator を使用して neck を凝固 する動脈瘤 neck 形成術8)について報告しているが，佐 野 ${ }^{9)}$ は, bipolar coagulation を行った血管壁を組織学的に 検索し, 凝固部位は变性し弾性板も断裂し, 一部は血管壁 内に出血を認め，この凝固部位が血管壁側に残存した場合 そこに新しい動脈瘤が発生したり，そこから出血する可能 性が十分に考えられると報告している。〈症例 2，3，4， 5〉ではneck 近くを凝固していた.

手術直後に再出血した 1 例を除き血圧は高めに経過して おり, 高い血圧レベルが残存 neck の破裂, clipの slip out を助長した可能性もある. 血管攣縮の時期が過ぎたら厳重 な血圧コントロールも必要である.

\section{結 語}

（1）1976年 4 月より1985年12月の間に開頭根治術を行っ た835個 (698症例) の脳動脈瘤中 7 症例 $(0.8 \%)$ に再出血が 認められた。

（2）再出血をきたした 7 症例は全例破裂脳動脈瘤処置 後の症例であり, 4 症例では incomplete clip, 3 症例では 
slipped clip が原因と考えられた.

( 3 ) clip の仕方が最も重要であるが, clip headへの周 囲脳組織の加重, 術後の血圧レベルの関与も考えられた.

\section{文献}

1）安井信之, 川村伸悟, 大田英則, ほか：脳動脈瘤破裂クモ 膜下出血の予後決定因子一新しい重症度分類について一. 第24回日本神経学会総会, 京都, 1983

2) Ito $\mathrm{Z}$ : Microsurgery of Cerebral Aneurysms. (ed by $\mathrm{N}$ Yasui), Elsevier Nishimura, Amsterdam, The Netherlands, 1985, pp 1-47

3）蛯名国彦，森山 隆，大熊洋揮，ほか：脳動脈瘤 wrapping に関する再検討. Neurol Med Chir (Tokyo) 25：455-462, 1985

4) Fox JL : Intracranial Aneurysms Vol II, Springer-Verlag,
New York, 1983, pp 708-734

5）関貫聖二，岡島和弘，佐藤浩一，ほか：脳動脈瘤クリッピ ング後の再発. 脳神経外科 13：1357-1362, 1985

6) Sugita K, Hirota T, Iguchi I, et al : Comparative study of the pressure of various aneurysm clips. J Neurosurg 44 : 723-727, 1976

7) Rosenbaum TJ, Sundt $T M$ : Interrelationship of aneurysm clips and vascular tissue. J Neurosurg $48: 929-934,1978$

8) Yaşargil MG, Fox JL, Ray MW : The operative approach to aneurysms of the anterior communicating artery. In : Krayenbühl H (ed), Advances and Technical Standards in Neurosurgery, Vol 2, Springer-Verlag, New York, 1975, pp 113-170

9）佐野公俊，星野正明，石山憲雄，ほか：動脈瘤 clipping に 際しての dome coagulation の有用性. 第12回脳卒中の外科 研究会講演集, にゅーろん社, 1983, pp 237-241 